\title{
Application of Novel Amino-Functionalized NZVI@SiO 2 Nanoparticles to Enhance Anaerobic Granular Sludge Removal of 2,4,6-Trichlorophenol
}

\author{
Zeyu Guan,' Jinquan Wan,, ${ }^{1,2}$ Yongwen Ma, ${ }^{1,2}$ Yan Wang, ${ }^{1,2}$ and Yajie Shu ${ }^{1}$ \\ ${ }^{1}$ College of Environmental Science and Engineering, South China University of Technology, Guangzhou 510006, China \\ ${ }^{2}$ State Key Laboratory of Pulp and Paper Engineering, South China University of Technology, Guangzhou 510006, China \\ Correspondence should be addressed to Zeyu Guan; guanzeyu1@126.com
}

Received 19 January 2015; Revised 31 March 2015; Accepted 1 April 2015

Academic Editor: Spyros P. Perlepes

Copyright (C) 2015 Zeyu Guan et al. This is an open access article distributed under the Creative Commons Attribution License, which permits unrestricted use, distribution, and reproduction in any medium, provided the original work is properly cited.

\begin{abstract}
A novel amino-functionalized silica-coated nanoscale zerovalent iron (NZVI@SiO $2-\mathrm{NH}_{2}$ ) was successfully synthesized by using one-step liquid-phase method with the surface functionalization of nanoscale zerovalent iron (NZVI) to enhance degradation of chlorinated organic contaminants from anaerobic microbial system. NZVI@SiO $2-\mathrm{NH}_{2}$ nanoparticles were synthesized under optimal conditions with the uniform core-shell structure $(80-100 \mathrm{~nm})$, high loading of amino functionality $(\sim 0.9 \mathrm{wt} \%)$, and relatively large specific surface area $\left(126.3 \mathrm{~m}^{2} / \mathrm{g}\right)$. The result demonstrated that well-dispersed $\mathrm{NZVI@SiO}{ }_{2}-\mathrm{NH}_{2}$ nanoparticle with $\mathrm{nFe}^{0}$-core and amino-functional silicon shell can effectively remove 2,4,6-trichlorophenol $(2,4,6-\mathrm{TCP})$ in the neutral condition, much higher than that of NZVI. Besides, the surface-modified nanoparticles $\left(\mathrm{NZVI@SiO}-\mathrm{NH}_{2}\right)$ in anaerobic granule sludge system also showed a positive effect to promote anaerobic biodechlorination system. More than $94.6 \%$ of 2,4,6-TCP was removed from the combined NZVI@SiO $2-\mathrm{NH}_{2}$-anaerobic granular sludge system during the anaerobic dechlorination processes. Moreover, adding the appropriate concentration of NZVI@SiO $2-\mathrm{NH}_{2}$ in anaerobic granular sludge treatment system can decrease the toxicity of 2,4,6-TCP to anaerobic microorganisms and improved the cumulative amount of methane production and electron transport system activity. The results from this study clearly demonstrated that the $\mathrm{NZVI@SiO}-\mathrm{NH}_{2}$ /anaerobic granular sludge system could become an effective and promising technology for the removal of chlorophenols in industrial wastewater.
\end{abstract}

\section{Introduction}

Chlorophenols (CPs), a group of toxic and suspected carcinogenic pollutants, have been widely identified in chemical industrial wastewater. CPs are considered resistant to biodegradation and may cause adverse effects on human health and the receiving environment [1-3]. The development of technologies for the remediation of CPs from industrial wastewater has attracted a great deal of attention in recent years, such as activated carbon absorption, photocatalytic degradation, electrochemical oxidation, and biodegradation [4-7]. Among these methods, anaerobic biological treatment technology is widely applied in toxic industrial wastewater treatment process due to convenient usage and economy $[8$, 9]. However, anaerobic microorganisms for treating industrial wastewater containing high concentration of CPs have technical limitations such as low degradation rates, long cleanup times, and inefficient activity of biological system, due to the unfavorable environmental conditions, properties of CPs, and their sterilized effects on microorganisms [10,11]. Therefore, it is necessary to develop the advanced anaerobic technologies with high biodegradation rates and suitable microbial system for removal and mineralization of CPs into harmless end products from industrial wastewater.

During the last decade, nanoscale zerovalent iron (NZVI) has been widely applied as a promising tool for the treatment of contaminated groundwater and soil [12]. NZVI can remove many kinds of recalcitrant pollutants such as chlorinated organic compounds, azo dyes, nitroaromatic pollutants, and heavy metals through reductive reaction mechanism [13-16]. Besides, NZVI-microorganisms system has also been conducted to investigate the codegradation 
pattern of chlorinated organics since they maintain a high removal rate and sufficient anaerobic microbial activity [17-19]. The role of NZVI is expected to help create an enhanced microbial environment combining all advantages of physical absorption, chemical reaction, and biodegradation. During the NZVI corrosion/hydrogen reduction reaction, the produced hydrogen gas has been considered as an electron-donor source for anaerobic microorganisms, such as methanogenic, homoacetogenic, sulfate-reducing bacteria and denitrifying bacteria [20-22]. Moreover, the removal of perchlorate, trichloroethylene, and $\mathrm{p}$-chloronitrobenzene can be improved through the combination of NZVI reduction with anaerobic microorganisms $[23,24]$. The removal of COD in integrated microbial- $\mathrm{Fe}^{0}$ treatment process also increased when compared with a control anaerobic reactor [17]. Thus, it is obviously worthy of enhancement of anaerobic biodegradation by adding iron-based nanoparticles. However, under the natural environment, using NZVI is highly controlled by its unique physical/chemical properties for treating chlorinated organics $[25,26]$. For example, the decreasing degradation rate of the chlorinated contaminants in practice process is mainly due to the particle devitalization and aggregation, and the high surface energy leads to the oxidation of iron nanoparticle in the atmosphere [27].

To overcome these problems, surface modification is recommended for synthesizing more stable and efficient NZVI. The surface modifying agents have been reported including carboxymethyl cellulose, chitosan, silica, and polymeric electrolyte membrane [28], which can be coated onto the surface of the nanoparticles to provide electrostatic repulsion and steric or electrosteric stabilization [14]. Compared with the organic coating materials, $\mathrm{SiO}_{2}$ has characteristics of water solubility, nontoxicity, and biocompatibility features. Additionally, the $\mathrm{SiO}_{2}$ coating shell has an abundance of surface hydroxyl groups, which makes it easy for surface modification and grafting functional groups [29, 30]. Silica-coated core-shell magnetite nanoparticles, that is, $\mathrm{Fe}_{3} \mathrm{O}_{4} @ \mathrm{SiO}_{2}$, have recently been prepared for potential biomedical applications [31]. Besides, amino-functionalized $\mathrm{Fe}_{3} \mathrm{O}_{4} @ \mathrm{SiO}_{2}$ core-shell magnetic nanomaterial has been prepared as a novel adsorbent for aqueous heavy metals removal [30]. Nevertheless, there are only a few researches about the synthesis and application of amino-functionalized silica-nanoscale zerovalent iron technology to improve the antioxidation abilities in the atmosphere and reduce degradation capacity in the actual water treatment process.

The objectives of this study were to develop a novel amino-functionalized silica-coated nanoscale zerovalent iron $\left(\mathrm{NZVI@SiO}{ }_{2}-\mathrm{NH}_{2}\right.$ ) by using a one-step Stöber method with the surface functionalization of NZVI. Batch microcosm experiments were executed to investigate the degradation efficiency of 2,4,6-TCP in the NZVI@SiO $-\mathrm{NH}_{2}$ /anaerobic granular sludge system and to assess nanoparticles influence on the anaerobic microbial activity. In addition, the effect of $\mathrm{NZVI@SiO} 2-\mathrm{NH}_{2}$ dosage and the role of $\mathrm{Fe}^{2+}$ on the removal of 2,4,6-TCP were also evaluated. The obtained results in this study will be useful to better understand the feasibility of using $\mathrm{NZVI@SiO} 2-\mathrm{NH}_{2}$-anaerobic granular sludge system for the remediation of industrial wastewater with CPs contamination.

\section{Materials and Methods}

2.1. Materials. Chemicals ferrous sulfate heptahydrate $\left(\mathrm{FeSO}_{4} \cdot 7 \mathrm{H}_{2} \mathrm{O}\right)$, ferric chloride hexahydrate $\left(\mathrm{FeCl}_{3} \cdot 6 \mathrm{H}_{2} \mathrm{O}\right)$, ferrous chloride tetrahydrate $\left(\mathrm{FeCl}_{2} \cdot 4 \mathrm{H}_{2} \mathrm{O}\right)$, isopropanol, tetraethyl orthosilicate (TEOS, $\geq 98.0 \%$ ), and methyl alcohol (99.93\%, HPLC grade) and other chemical reagents were purchased from the Jinke Chemical Reagent Co., Ltd. (Guangzhou, China). 3-Aminopropyl trimethoxysilane (APTMS, $\geq 97.0 \%$ ), poly(ethylene glycol) (PEG20000, $\geq 96.0 \%$ ), and 2,4,6-trichlorophenol (2,4,6-TCP, 98\%) were purchased from Aladdin Chemistry Co., Ltd. (China). All chemical solutions and reagents used in the experiments were of analytical grade without further purification.

The tested sludge used as the inoculum for batch experiment was taken from an industrial wastewater treatment plant of pulp and paper mill in Guangzhou. The ratio of volatile suspended sludge to total suspended sludge (VSS/TSS) of this sludge was 0.79 . In order to avoid the interference of the residual contaminants in the growth environment for the removal experiments, the anaerobic granular sludge was washed with $\mathrm{N}_{2}$-sparged deionized water.

2.2. Synthesis of NZVI@SiO $-\mathrm{NH}_{2}$. Nanoscale zerovalent iron (NZVI) was firstly prepared using conventional liquid-phase reduction by reducing $\mathrm{FeSO}_{4}$ with an excess of $\mathrm{NaBH}_{4}[14$, 32]. The coating iron nanoparticle with silica ( $\mathrm{NZVI@SiO} 2$ ) was prepared based on a Stöber method using silicon alkoxide as a silica source. In brief, three grams of $\mathrm{FeSO}_{4} \cdot 7 \mathrm{H}_{2} \mathrm{O}$ was diluted in the $150 \mathrm{~mL}$ ultrapure water/isopropanol $(1: 2, \mathrm{v}: \mathrm{v})$ solution and stirred in a three-neck flask at room temperature. Then, $30 \mathrm{~mL}$ of freshly prepared $\mathrm{NaBH}_{4}$ solution $(1 \mathrm{~mol} / \mathrm{L})$ was added dropwise under nitrogen protection, resulting in a suspension of iron nanoparticles. Finally, $4 \mathrm{~mL}$ of TEOS and $1 \mathrm{~mL} \mathrm{NaOH}$ solution were added to the above iron nanoparticle solution to generate the $\mathrm{NZVI@SiO}$.

Amino-functionalized silica-nanoscale zerovalent iron (NZVI@SiO $-\mathrm{NH}_{2}$ ) was conducted on-site by APTMS as the modified agent. After the above coating process for $4 \mathrm{~h}, 0.8 \mathrm{~mL}$ of APTMS was then added to the suspension, and the mixture was preserved at room temperature with continuous stirring $(150 \mathrm{rmp} / \mathrm{min})$ for $12 \mathrm{~h}$ under nitrogen flow $(40 \mathrm{~mL} / \mathrm{min})$. After the reaction, the fresh $\mathrm{NZVI@SiO}_{2}$ $\mathrm{NH}_{2}$ nanoparticles were separated and washed several times with deionized water and ethanol to remove associated polysiloxane and dried overnight at $60^{\circ} \mathrm{C}$ under vacuum.

\subsection{Batch Experiments for 2,4,6-TCP Removal}

2.3.1. Removal of 2,4,6-TCP by Iron Nanoparticles in Aqueous System. The removal experiments of 2,4,6-TCP by NZVI, $\mathrm{NZVI@SiO} 2$, and $\mathrm{NZVI@SiO}-\mathrm{NH}_{2}$ were conducted in $250 \mathrm{~mL}$ saline bottles. 2,4,6-TCP (50 mg/L) was firstly spiked into the $\mathrm{N}_{2}$-sparged deionized water, and then iron samples 
$(0.5 \mathrm{~g} / \mathrm{L})$ including NZVI, NZVI@SiO${ }_{2}$, and NZVI@SiO ${ }_{2}^{-}$ $\mathrm{NH}_{2}$ were added to these TCP solutions, respectively. The reaction solution was deoxygenated by $\mathrm{N}_{2}$ stream for another $15 \mathrm{~min}$ and kept sealed with a rubber stopper during the reaction. The final volume of reaction solution was $200 \mathrm{~mL}$ at $\mathrm{pH}$ value of 7.0 which was adjusted by $\mathrm{HCl}$ or $\mathrm{NaOH}$. The serum bottles were performed in a thermostatic incubator at $35^{\circ} \mathrm{C}$ with a rotation speed of $150 \mathrm{rpm}$. At given time intervals, an aliquot of reaction solution was sampled for the measurement of residual 2,4,6-TCP concentration and $\mathrm{pH}$ value.

2.3.2. Removal of 2,4,6-TCP by the Integrated NZVI@SiO ${ }_{2}^{-}$ $\mathrm{NH}_{2}$-Anaerobic Microorganism System. Three parallel nanobiodegradation hybrid systems for 2,4,6-TCP removal were performed by using $250 \mathrm{~mL}$ saline bottles with rubber stoppers as anaerobic microcosm reactors: the combination of anaerobic granular sludge system/NZVI (AGS + NZVI), the combination of anaerobic granular sludge/NZVI@SiO system (AGS + NZVI@SiO ${ }_{2}$ ), and the combination of anaerobic granular sludge/NZVI@SiO $2-\mathrm{NH}_{2}$ system (AGS + NZVI@SiO ${ }_{2}-\mathrm{NH}_{2}$ ). The synthetic nutrient solution in each system was deoxygenated at $\mathrm{pH} 7.0$ including a certain amount of 2,4,6-TCP, $10 \mathrm{~g}$ VSS anaerobic granular sludge, and the same dose of nanoparticles of $0.5 \mathrm{~L}^{-1}$. Two control experiments were also conducted to clarify the intimal activity of anaerobic microorganism and the toxicity of TCP on the biodegradation: a single anaerobic granular sludge system (AGS) was the same as the mixed system, but without any iron nanoparticle; another common anaerobic biodegradation system (AGS only) was the same as AGS, except without the 2,4,6-TCP. The composition of synthetic nutrient solution in biodegradation experiment included $3000 \mathrm{mg} / \mathrm{L}$ glucose, $286 \mathrm{mg} / \mathrm{L}$ ammonium chloride, and $65 \mathrm{mg} / \mathrm{L}$ monopotassium phosphate as nutrient and energy source to facilitate growth of the biomass, with $\mathrm{C} / \mathrm{N} / \mathrm{P}$ ratio of $200: 5: 1$. In addition, $1 \mathrm{~mL}$ stock solution liquor of necessary trace elements was added to the above solution containing the following composition (mg/L): $\mathrm{CaCl}_{2} \cdot 2 \mathrm{H}_{2} \mathrm{O}, 330$; EDTA, $5000 ; \mathrm{NiCl}_{2} \cdot 6 \mathrm{H} 2 \mathrm{O}, 190 ; \mathrm{H}_{3} \mathrm{BO}_{4}, 14 ; \mathrm{ZnCl}_{2}, 205 ; \mathrm{MnSO}_{4}, 500$; $\mathrm{CuSO}_{4} \cdot 5 \mathrm{H}_{2} \mathrm{O}, 250 ; \mathrm{CoCl}_{2} \cdot 6 \mathrm{H}_{2} \mathrm{O}, 240 ; \mathrm{MnCl}_{2} \cdot 4 \mathrm{H}_{2} \mathrm{O}, 205$; $(\mathrm{NH} 4)_{6} \mathrm{MoO}_{4} \cdot 4 \mathrm{H}_{2} \mathrm{O}, 9$. The saline bottles were maintained in a constant temperature shaker at $35^{\circ} \mathrm{C}$ with a rotation speed of $150 \mathrm{rpm}$. At various time intervals, $2 \mathrm{~mL}$ of suspensions was withdrawn from each reactor and control bottle for the analysis of degradation rate of 2,4,6-TCP. Besides, the removal rate, methanogenic activity, and electron transport system (ETS) activity were measured in duplicate.

2.4. Analytical Methods. The prepared iron nanoparticles were characterized as follows. The surface morphology and size distribution were determined with an S-3700N scanning electron microscopy (SEM) characterization (Hitachi, Japan). The elemental composition was performed by energydispersive spectrometry (EDS, Bruker Quantax, Germany), with energy resolution $123 \mathrm{eV}$. The crystallographic structures of these nanoparticles and oxides were determined by a D8 Advance X-ray Diffraction system and Bruker AXS with a
$\mathrm{Cu}$ target and $\mathrm{K} \alpha$ radiation $(\lambda=0.15418 \mathrm{~nm})$ at $40 \mathrm{kV}$ and $40 \mathrm{~mA}$ at $20^{\circ} \mathrm{C}$. The scan rate was set at $1.2^{\circ} / \mathrm{min}$, and the range was set from 10 to $80(2 \theta)$. FT-IR spectra were measured by a Spectrum One-B FT-IR spectrophotometer (Nicolet Magna 550) under dry air at $20^{\circ} \mathrm{C}$ by a $\mathrm{KBr}$ pellets method. Each sample was scanned from 4000 to $400 \mathrm{~cm}^{-1}$ with a resolution of $4 \mathrm{~cm}^{-1}$. The sampled 2,4,6TCP reaction solution was firstly centrifuged for $10 \mathrm{~min}$ at $10000 \mathrm{~g}$, and the supernatant was filtered through a $0.45 \mu \mathrm{m}$ hydrophilic polyethersulfone (PES) syringe filter for highperformance liquid chromatography (HPLC) analysis. 2,4,6TCP was analyzed on a Shimadzu LC-2010A HPLC equipped with a UV detector. A C18 column $(250 \times 4.6 \mathrm{~mm}, 15 \mu \mathrm{m})$ was used for the separation. The column temperature was set at $30^{\circ} \mathrm{C}$. Methyl alcohol and ultrapure water $(80: 20$, $\mathrm{v} / \mathrm{v})$ were used as the mobile phase. The flow rate was set at $0.7 \mathrm{~mL} / \mathrm{min}$. The UV wavelength for 2,4,6-TCP detection was $290 \mathrm{~nm}$. Electron transport system (ETS) activity was measured by an INT method for assessing metal influence on anaerobic sludge $[33,34]$. A Shi's fermentation tube was used to measure biogas production. The gas composition of biogas was investigated using gas chromatography (A90, Echrom, China). Methane gas was analyzed with a $2 \mathrm{~m} \times$ $8 \mathrm{~mm}$ stainless column packed with Porapak T (80/100 mesh) and the operational temperatures of detector, injection port, and column were set at $250^{\circ} \mathrm{C}, 200^{\circ} \mathrm{C}$, and $100^{\circ} \mathrm{C}$, respectively. Argon was used as a carrier gas with a flow rate of $30 \mathrm{~mL} / \mathrm{min}$.

\section{Results and Discussion}

\subsection{Characterization of NZVI@SiO $2-\mathrm{NH}_{2}$}

3.1.1. The Morphology and Composition. The morphology, nanoparticle distribution, and element content of freshly prepared NZVI and NZVI@SiO $2-\mathrm{NH}_{2}$ were presented in Figure 1. All these freshly synthesized NZVI particles were tightly touching each other in roughly spherical forms (Figure 1(b)), possibly due to their aggregation properties in the aqueous solution and their tendency to remain in the most thermodynamically favorable state. On the contrary, the obtained NZVI@SiO $2-\mathrm{NH}_{2}$ nanoparticles showed a smoothly spherical shape (Figure 1(a)) and were uniformly covered by an amorphous outer layer of $\mathrm{SiO}_{2}$ (Figure 1(c)). SEM image of NZVI@SiO $\mathrm{SH}_{2}-\mathrm{NH}_{2}$ indicated an average diameter range of about $80-100 \mathrm{~nm}$, while the NZVI particles ranged from 30 to $60 \mathrm{~nm}$. The diameter of iron nanoparticles increased with the coating and surface modification.

The chemical composition of NZVI and NZVI@SiO ${ }_{2}^{-}$ $\mathrm{NH}_{2}$ was also determined by EDS in Figure 2, which can be used to confirm the relation between the changes of particle morphology and the size with the appearing $\mathrm{SiO}_{2}$ layer. The chemical composition of NZVI was $0.14 \mathrm{wt} \%$ of $\mathrm{C}$, $8.88 \mathrm{wt} \%$ of $\mathrm{O}$, and $91.03 \mathrm{wt} \%$ of $\mathrm{Fe}$, while the NZVI@SiO${ }_{2}$ $\mathrm{NH}_{2}$ was of $5.9 \mathrm{wt} \%$ of $\mathrm{Si}, 19.45 \mathrm{wt} \%$ of $\mathrm{O}$, and $74.65 \mathrm{wt} \%$ of $\mathrm{Fe}$, reflecting the coating of $\mathrm{SiO}_{2}$ on the NZVI surface. Moreover, the successful amino-functionalization of $\mathrm{SiO}_{2}$ layer was also indicated by $\mathrm{CHN}$ elemental analysis. The nitrogen content was in a proper range from 0.6 to $0.9 \%$ 


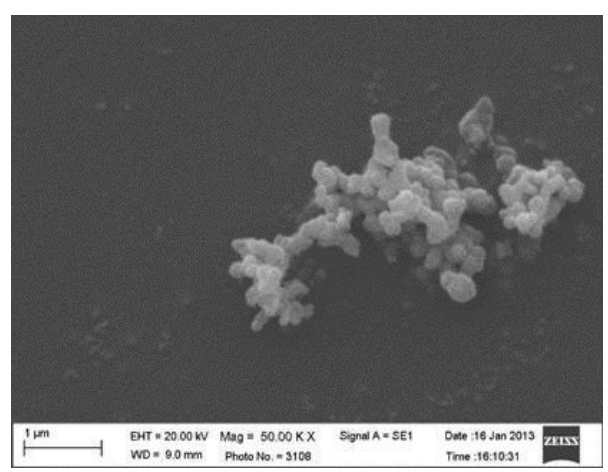

(a)

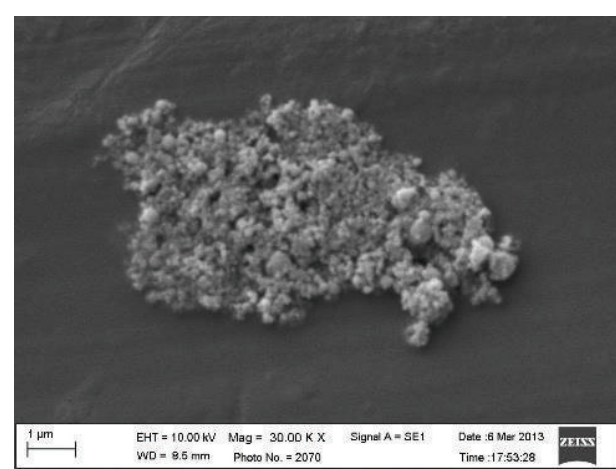

(b)

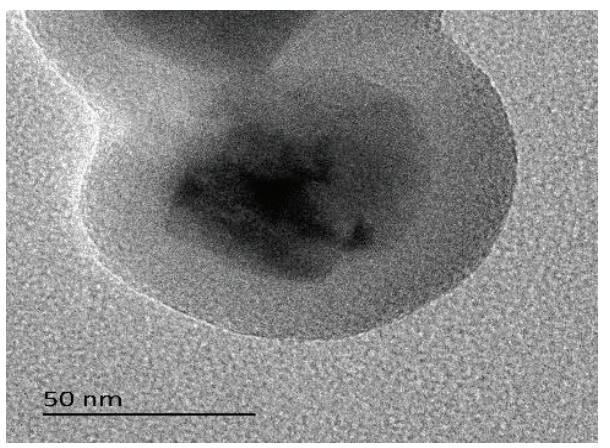

(c)

FIgURE 1: The surface morphology of freshly prepared NZVI@SiO $-\mathrm{NH}_{2}$ and NZVI: (a) SEM image of the $\mathrm{NZVI@SiO}_{2}-\mathrm{NH}_{2}$, (b) SEM image of the NZVI, and (c) TEM image of the NZVI@SiO $2-\mathrm{NH}_{2}$.

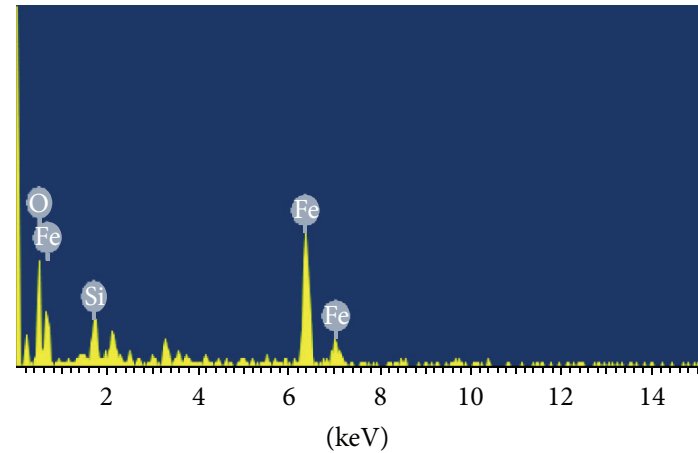

Full scale 91 cts cursor 0.000

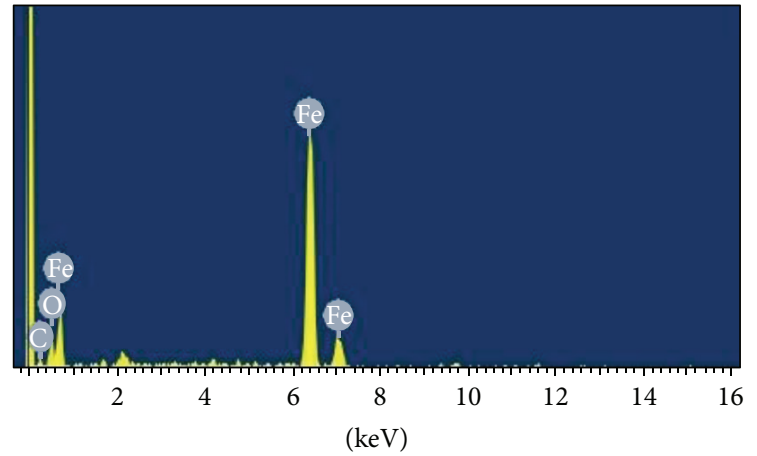

Full scale 247 cts cursor 0.000

(a)

(b)

FIGURE 2: The surface elemental composition of freshly prepared NZVI@SiO $-\mathrm{NH}_{2}$ and NZVI: (a) EDS image of the $\mathrm{NZVI@SiO}_{2}-\mathrm{NH}_{2}$ and (b) EDS image of the NZVI.

wt. on the NZVI@SiO $-\mathrm{NH}_{2}$, while it was not detected on the surface of NZVI. The result confirmed the structure of a $\mathrm{SiO}_{2}$ shell on the $\mathrm{nFe}^{0}$-core surface and the aminopropyl modification of the $\mathrm{SiO}_{2}$ shell.

3.1.2. X-Ray Powder Diffraction and FT-IR Spectroscopy. To better understand the primary characterization of the chemical and physical properties of the modified iron nanoparticle, XRD and FT-IR measurements were also made on NZVI and NZVI@SiO $2-\mathrm{NH}_{2}$ in Figure 3(a). Evidently, the same characteristic peaks were observed for NZVI@SiO $-\mathrm{NH}_{2}$ and NZVI with a strong peak at $2 \theta=44.76^{\circ}$ and two weak peaks at $2 \theta=65.16^{\circ}$ and $82.48^{\circ}$, indicative of the body-centered cubic $\alpha-\mathrm{Fe}^{0}$ in the internals of the modified iron nanoparticle. The crystalline phase of iron nanoparticles was stable during silica coating and surface amino-functionalization process [35]. In contrast to the other characteristic peaks of the NZVI, the NZVI@SiO $-\mathrm{NH}_{2}$ showed an extra-large shoulder centered around $2 \theta=23^{\circ}$, which can be ascribed to the existence of amorphous silica component; and no obvious peaks have 


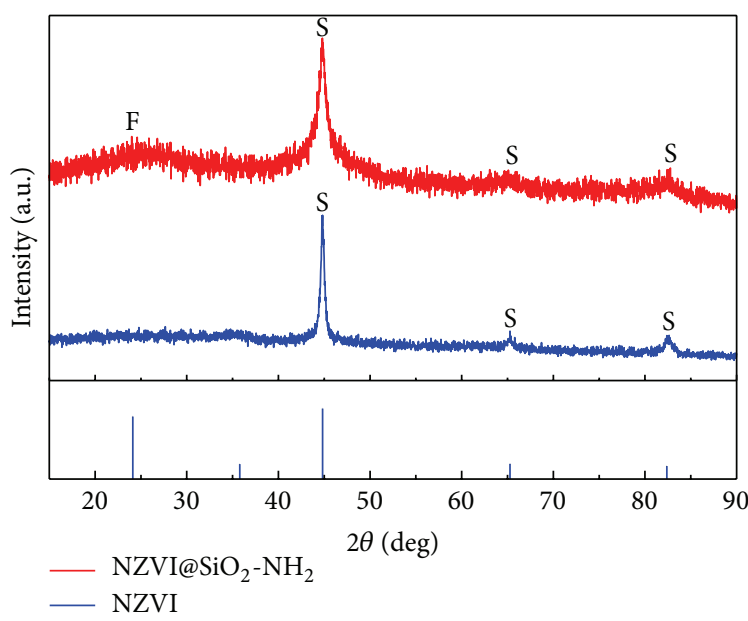

(a)

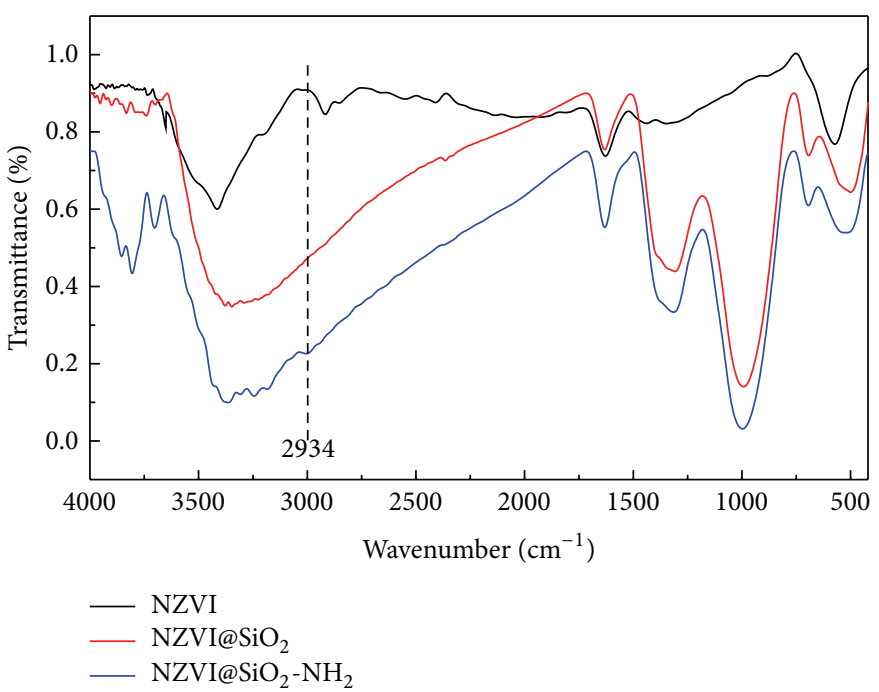

(b)

FIGURE 3: XRD and FT-IR patterns produced the different style iron nanoparticle.

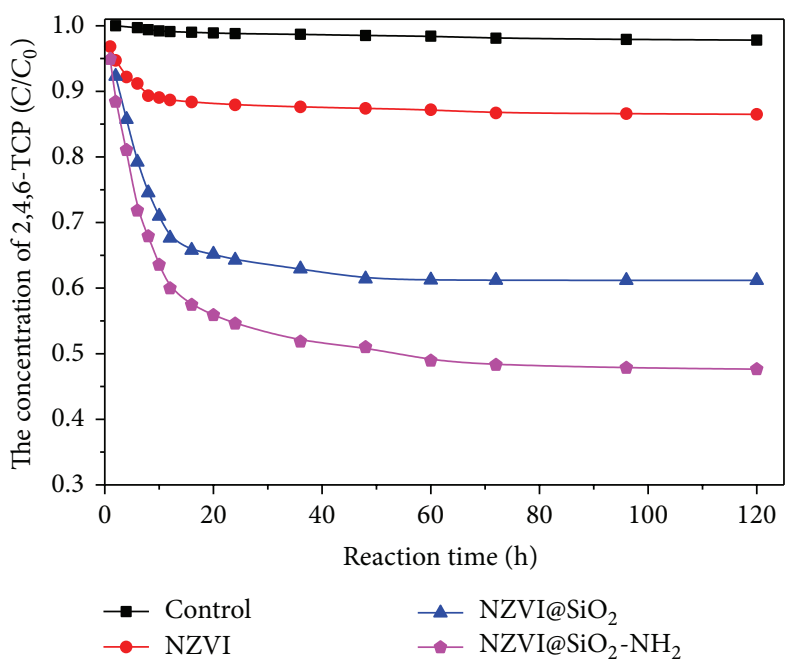

(a)

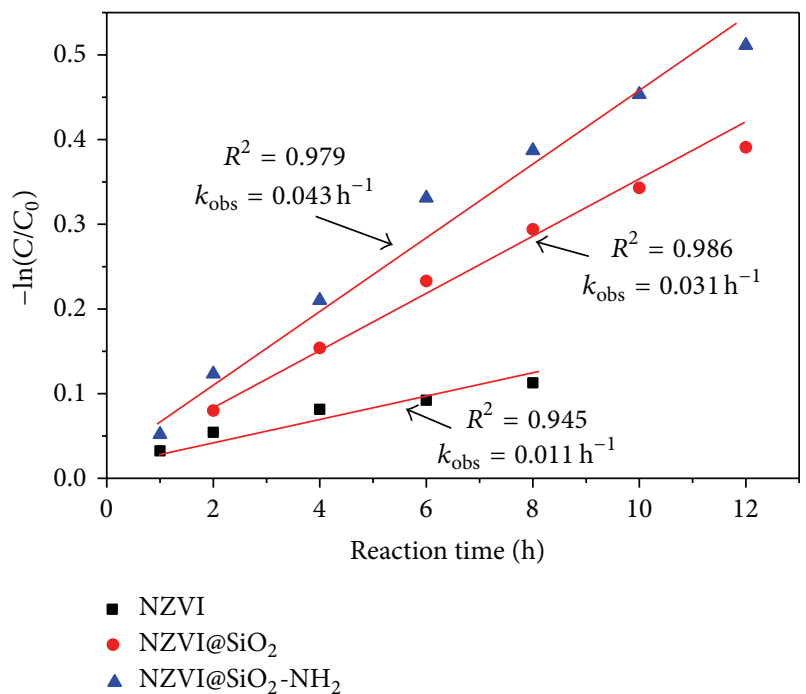

(b)

FIGURE 4: (a) The degradation of 2,4,6-TCP under different iron nanoparticle systems; (b) reaction kinetic plots for the degradation of 2,4,6TCP versus time.

shown the existence of the iron oxide as $\alpha-\mathrm{Fe}_{2} \mathrm{O}_{3}$ at $2 \theta=36^{\circ}$. Thus, it proved the presence of the silica shells on the surface of $\mathrm{nFe}^{0}$-core after the modified process. The FT-IR spectra for $\mathrm{SiO}_{2}$ coating layer and $\mathrm{NH}_{2}$-functional group were obviously discerned on the surface of NZVI@SiO ${ }_{2}-\mathrm{NH}_{2}$ in Figure 3(b). Compared to NZVI, the characteristic peaks of $1057 \mathrm{~cm}^{-1}$ in $\mathrm{NZVI@SiO}$ and $\mathrm{NZVI@SiO} 2-\mathrm{NH}_{2}$ were attributed to the $\mathrm{Si}-$ $\mathrm{O}-\mathrm{Si}$ asymmetric stretching vibration which indicated the formation of silica shells on the surface of $\mathrm{nFe}^{0}$-core. In addition, the typical peak at $2934 \mathrm{~cm}^{-1}$ corresponding to $\mathrm{CH}_{2}-$ group of aminopropyl from APTMS molecules was attributed to the characteristic peaks of the amine groups, indicating the success of the aminopropyl functionalization onto the surface of NZVI@SiO $-\mathrm{NH}_{2}$ particles during the sequential sol-gel process [30].

3.2. TCP Dechlorination by the NZVI@SiO ${ }_{2}-\mathrm{NH}_{2}$ in Aqueous System. The reaction reactivity of the iron nanoparticles on 2,4,6-TCP dechlorination could depend on the physicalchemical characteristic of nanoparticles. The effect of modified process on reaction reactivity was evaluated by the degradation efficiency of 2,4,6-TCP in aqueous phase. The results of removal of 2,4,6-TCP by NZVI, NZVI@SiO and NZVI@SiO $2-\mathrm{NH}_{2}$ were displayed in Figure 4(b). In the control experiment, the concentrations of 2,4,6-TCP existed steadily over $120 \mathrm{~h}$ in anoxic aqueous solution without any 


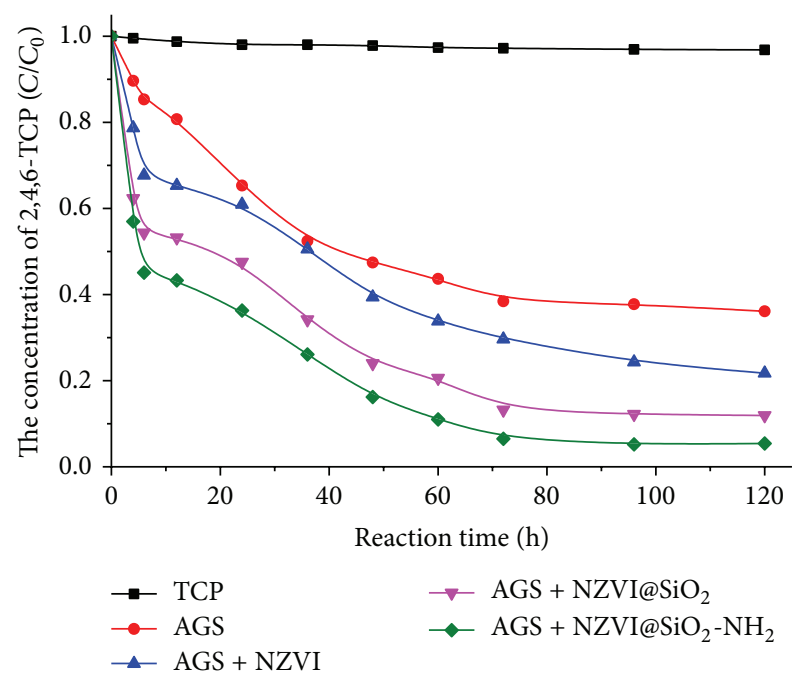

FIGURE 5: The degradation of 2,4,6-TCP in anaerobic granule sludge system adding different iron nanoparticle.

iron nanoparticles. The concentration of 2,4,6-TCP decreased obviously with the increasing reaction time by different styles of iron nanoparticles in anoxic conditions. However, for NZVI, only about $14 \%$ of the 2,4,6-TCP was degraded within 120 h. On the contrary, NZVI@SiO ${ }_{2}$ and NZVI@SiO ${ }_{2}$ $\mathrm{NH}_{2}$ exhibited high reactivity toward 2,4,6-TCP degradation, with the removal rates of $38.9 \%$ and $52.3 \%$ within $120 \mathrm{~h}$, respectively. On the one hand, the reduction capacity of iron nanoparticles was very sensitive to the water/oxygen in the surrounding media [36]. The freshly prepared NZVI was rapidly corroded and formed an oxidation film, resulting in the loss of reactivity, which may decline and delay the reactivity of further reaction with 2,4,6-TCP. Meanwhile, the higher removal rates of 2,4,6-TCP by NZVI@SiO $-\mathrm{NH}_{2}$ and NZVI@SiO $\mathrm{S}_{2}$ may come from the increased antioxidant capacity by $\mathrm{SiO}_{2}$ coating [37]. On the other hand, $\mathrm{SiO}_{2}$ cladding layer and $\mathrm{NH}_{2}$-functional groups of the modified iron nanoparticles could be used to enlarge the specific surface area and kept more surface active points, leading to the higher surface reactivity and faster contaminants removal rate. The specific surface area analysis showed that $\mathrm{NZVI@SiO}{ }_{2}-\mathrm{NH}_{2}$ and $\mathrm{NZVI@SiO}{ }_{2}$ had higher BET surface areas of $126.3 \mathrm{~m}^{2} / \mathrm{g}$ and $107.4 \mathrm{~m}^{2} / \mathrm{g}$ than that of NZVI $\left(67.3 \mathrm{~m}^{2} / \mathrm{g}\right)$. Besides, the hydrophobic surface properties of $\mathrm{NZVI@SiO} \mathrm{O}_{2}-\mathrm{NH}_{2}$ were also improved by the introduced functional groups, resulting in good dispersibility, which could effectively improve the chance to contact with the active sites in surface of the nanoparticles and contaminants, thereby increasing the removal efficiency. At the initial reaction, removal of 2,4,6-TCP by NZVI, NZVI@SiO 2 , and $\mathrm{NZVI@SiO} \mathrm{O}_{2}-\mathrm{NH}_{2}$ under different reaction time could be described by first-order rate equation in different reaction time. The result was presented in Figure 4(b). The obtained $k_{\text {obs }}$ value was only $0.011 \mathrm{~h}^{-1}$ for the NZVI reaction with 2,4,6TCP. The degradation efficiencies of modified NZVI@SiO and NZVI@SiO ${ }_{2}-\mathrm{NH}_{2}$ were $0.031 \mathrm{~h}^{-1}$ and $0.043 \mathrm{~h}^{-1}$, much higher than that of NZVI, indicating that introducing $\mathrm{SiO}_{2}$ cladding layer and $\mathrm{NH}_{2}$-functional groups could enhance their ability of reductive dechlorination.

\subsection{TCP Dechlorination by the Combination of Anaerobic Granule Sludge/NZVI@SiO ${ }_{2}-\mathrm{NH}_{2}$ System}

3.3.1. Influence of NZVI@SiO $-\mathrm{NH}_{2}$ on the Anaerobic Biodegradation of 2,4,6-TCP. Application of anaerobic microbial processes for the treatment of chlorinated organic compounds had drawn considerable attention in recent decade $[38,39]$. Under unfavorable environmental conditions, maintaining a stable microbial activity during degradation of toxic organic pollutants was one of the challenges in anaerobic treatment process which could lead to irreversible reactor failure. In this study, batch microcosm experiments were used to investigate the microbial activity profiles of the function of $\mathrm{NZVI@SiO}{ }_{2}-\mathrm{NH}_{2}$ on anaerobic granular sludge treating CPs. The influences of NZVI, NZVI@SiO ${ }_{2}$, and NZVI@SiO $-\mathrm{NH}_{2}$ on the removal of 2,4,6-TCP in the anaerobic biochlorination system were compared in Figure 5. For the AGS system, anaerobic microorganism alone could biologically degrade $2,4,6$-TCP slowly with the removal rate less than $70 \%$ during the $120 \mathrm{~h}$ experimental period. It was difficult to achieve complete degradation by only microbial action [40]. When $\mathrm{NZVI@SiO}{ }_{2}-\mathrm{NH}_{2}$ was added to anaerobic microbial system, more than $90 \%$ of $2,4,6$-TCP was removed from the system in $120 \mathrm{~h}$. Consistent with the earlier studies, adding NZVI in anaerobic system was a promising approach to promote anaerobic microbial biochlorination [13]. It is noteworthy that adding the surface-modified nanoparticle (NZVI@SiO ${ }_{2}$ $\mathrm{NH}_{2}$ and NZVI@SiO 2 ) to anaerobic granule sludge system was also capable of providing positive effect to promote anaerobic biochlorination processes. At the same time, the degradation efficiency of anaerobic microbial system for adding NZVI@SiO $2-\mathrm{NH}_{2}, 94.6 \%$ of 2,4,6-TCP removal, was substantially higher than that from adding NZVI@SiO ${ }_{2}$ and NZVI, $88.1 \%$ and $78.3 \%$ of 2,4,6-TCP removal, respectively. The experimental results showed that surface-modified and amino-functionalized $\mathrm{NZVI@SiO} 2-\mathrm{NH}_{2}$ could effectively maintain more particle surface activity and improve the dispersibility, thereby improving the ability of the combination system to remove $2,4,6$-TCP.

In order to explore the effect of $\mathrm{NZVI@SiO} 2-\mathrm{NH}_{2}$ further in anaerobic granule sludge system, the concentration of $\mathrm{Fe}^{2+}$ and $\mathrm{pH}$ were analyzed. Free ferrous iron were stared as the important iron reagents in practical application of environment. It can be found in Figure 6(a) that the concentration of $\mathrm{Fe}^{2+}$ was very low in NZVI/AGS system. In contrast, the concentration of $\mathrm{Fe}^{2+}$ went up sharply from 0 to $38.7 \mathrm{mg} / \mathrm{L}$ and $32.4 \mathrm{mg} / \mathrm{L}$ in $\mathrm{NZVI@SiO}{ }_{2}-\mathrm{NH}_{2} / \mathrm{AGS}$ and NZVI@SiO ${ }_{2}$ /AGS system, respectively. The concentration of $\mathrm{Fe}^{2+}$ was released from the $\mathrm{Fe}^{0}$ reaction, which could reflect the activity of the iron nanoparticle. However, if the freshly prepared NZVI was exposed in the atmosphere, air and water would trigger a rapid reaction with a large amount of iron corrosion product which formed the oxide layer on the surface of NZVI, identified by the earlier reports 


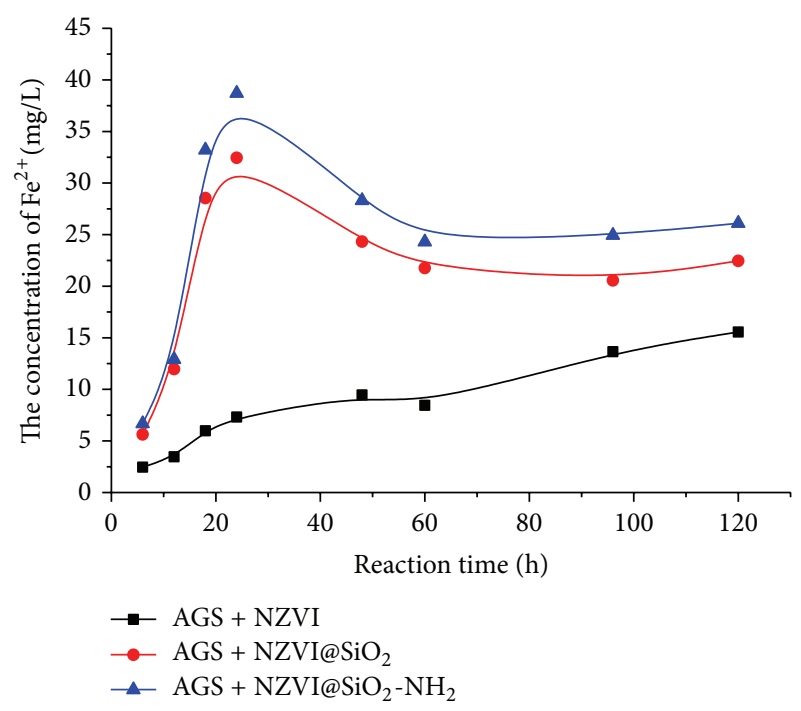

(a)

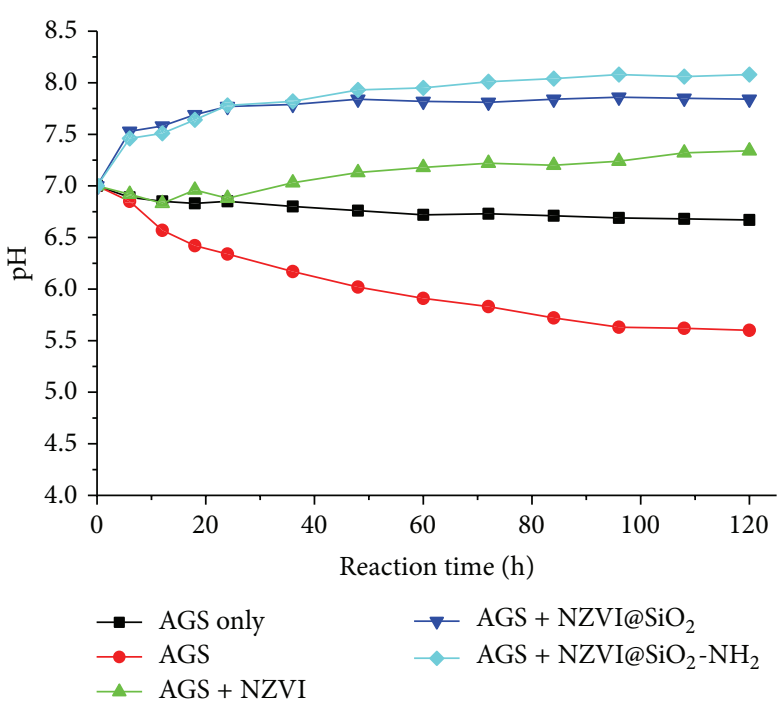

(b)

FIGURE 6: The variation of $\mathrm{pH}$ and $\mathrm{Fe}^{2+}$ during reaction: (a) the concentration of $\mathrm{Fe}^{2+}$ and total iron and (b) $\mathrm{pH}$.

as magnetite, maghemite, and lepidocrocite [41]. Once the surface of NZVI was coated by corrosion product, only negligible $\mathrm{Fe}^{0}$ reduction reaction would occur, leading to little of $\mathrm{Fe}^{2+}$ being released into the reaction medium. Thus, the aminopropyl modification of $\mathrm{SiO}_{2}$ shell could effectively slow down the surface passivation of nanoparticles, and ferrous ion could migrate almost freely in the functionalization of layer.

Meanwhile, it has been widely reported that $\mathrm{pH}$ was one of the significance factors for the growth of anaerobic microbial activity and the degradation efficiency of chlorinated organic pollutants in anaerobic microbial system. As shown in Figure 6(b), the $\mathrm{pH}$ of AGS decreased to 5.6 when adding $2,4,6$-TCP to the reaction medium, while the AGS only system was stable at 6.8 . This may be due to the inhibition of anaerobic microbial growth and methanogens activity from the toxic chlorophenols, which would produce the accumulation of organic acids. With NZVI@SiO $-\mathrm{NH}_{2}$ added, a gradual pH rise was observed in the AGS/NZVI@SiO $2^{-}$ $\mathrm{NH}_{2}$ system, which could be explained by the fact that $\mathrm{H}^{+}$ was required for the dissolution of iron and the iron hydroxide was positively charged by adsorbing $\mathrm{H}^{+}$[42]. Adding $\mathrm{NZVI@SiO}{ }_{2}-\mathrm{NH}_{2}$ could stabilize the reaction environment and maintain the activity of microorganism in the $\mathrm{nFe}^{0}$ microbial system. Considering that the reaction medium was unbuffered when the anaerobic granule sludge was exposed to $2,4,6$-TCP, the relative change of $\mathrm{pH}$ in the nanobiosystem was directly affected by the reaction activity of nanoparticle: the NZVI@SiO $-\mathrm{NH}_{2}$ induced increase in $\mathrm{pH}$ and was in excess of 0.21 and $0.74 \mathrm{pH}$ units compared to $\mathrm{NZVI@SiO}$ and NZVI at the $120 \mathrm{~h}$ of experiment process. Thus, these results proved that $\mathrm{NZVI@SiO} 2-\mathrm{NH}_{2}$ had a higher activity than NZVI and NZVI@SiO 2 . Consequently, it is confirmed that the NZVI@SiO $-\mathrm{NH}_{2}$ would contribute to the higher removal rate of 2,4,6-TCP, the plenty of electron donors, and the stable environment in the anaerobic granule, which further augmented the function of NZVI in the removal of chlorinated organic compounds.

3.3.2. Influence of $\mathrm{NZVI@SiO} 2-\mathrm{NH}_{2}$ on the Anaerobic Microbial Activity. To estimate the actual effect of $\mathrm{NZVI@SiO}_{2}-$ $\mathrm{NH}_{2}$ particles on methane production, the yield of biogas and the content of methane on the combination of AGS/NZVI@SiO $2-\mathrm{NH}_{2}, \mathrm{AGS} / \mathrm{NZVI@SiO}$, and AGS/NZVI system and the AGS system were shown in Figure 7 during the operation. The accumulative production of biogas was $273.5 \mathrm{~mL}, 242.7 \mathrm{~mL}$, and $204.6 \mathrm{~mL}$ in the anaerobic system enhanced by $\mathrm{NZVI@SiO}-\mathrm{NH}_{2}, \mathrm{NZVI@SiO} 2$, and NZVI, respectively, in contrast with $168.3 \mathrm{~mL}$ in the control system. In all cases, the yield of biogas was the highest in AGS/NZVI@SiO $-\mathrm{NH}_{2}$ system, increasing 12.5\% and 33.7\% when NZVI@SiO 2 and NZVI were supplied, respectively. Apparently, the higher activity of $\mathrm{NZVI@SiO} 2-\mathrm{NH}_{2}$ available led to plenty of electron donors and a stale and low toxic environment in anaerobic dechlorination process, which could stimulate methanogenesis dramatically. Moreover, the subdued period of methane production was shortened in the anaerobic system enhanced by NZVI@SiO $-\mathrm{NH}_{2}$ than AGS/NZVI@SiO 2 , AGS/NZVI, and the AGS system. The highest methane production increased gradually to a daily maximum of $42.2 \mathrm{~mL} / \mathrm{g} \mathrm{VSS} \mathrm{d}$ on the 20 th hour during the experiment, with methane content increasing $65.4 \%$. Therefore, the present study provided a clear demonstration that the AGS-NZVI@SiO $-\mathrm{NH}_{2}$ exhibits better performance in terms of higher methane production and shorter subdued period.

Electron transport system (ETS) activity of the combined AGS/NZVI@SiO $-\mathrm{NH}_{2}$ system was also further analyzed by the INT method to describe the influence of $\mathrm{NZVI@SiO}_{2}$ $\mathrm{NH}_{2}$ on dehydrogenase activity of anaerobic sludge, as shown 


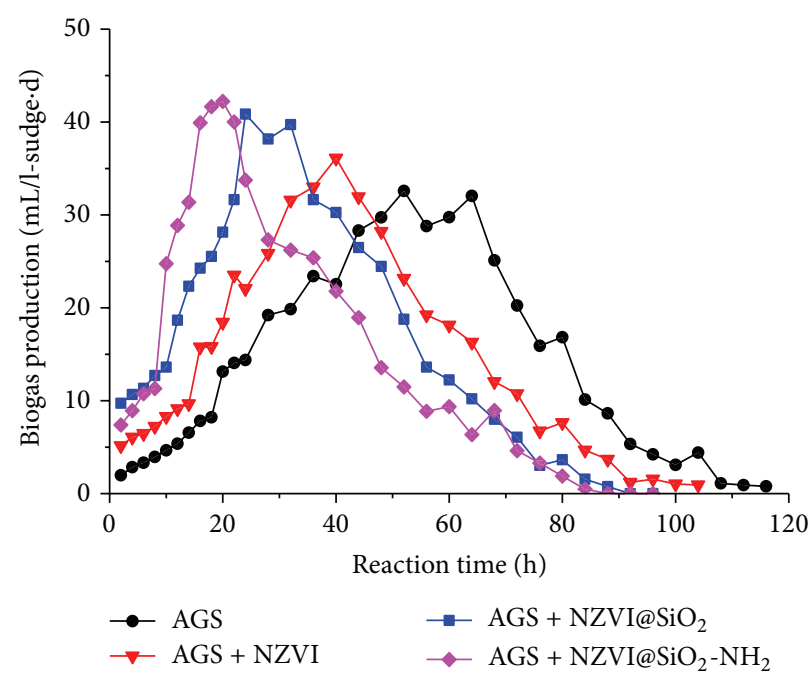

(a)

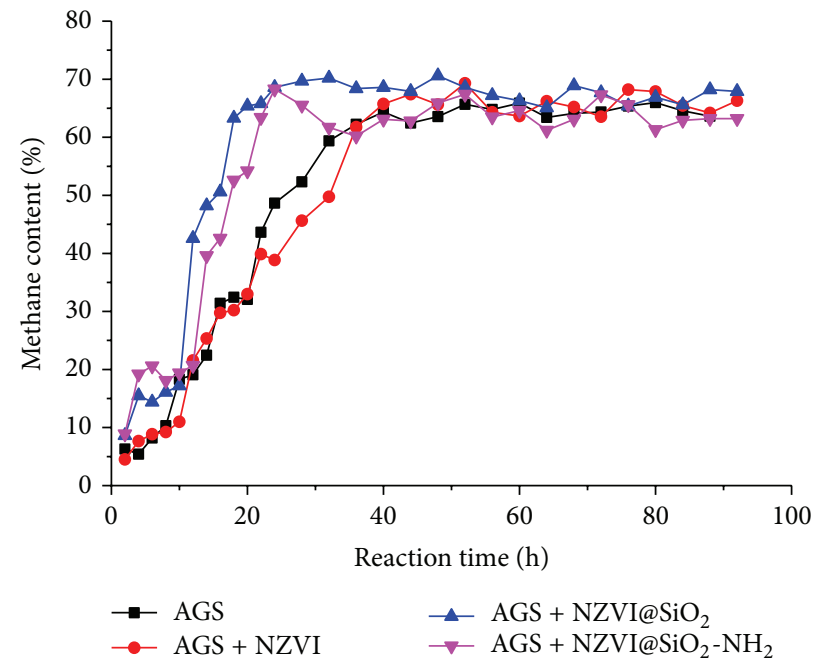

(b)

FIGURE 7: Effect of NZVI@SiO $-\mathrm{NH}_{2}$ on the yield (a) and concentration (b) of methane production in anaerobic granule sludge system.

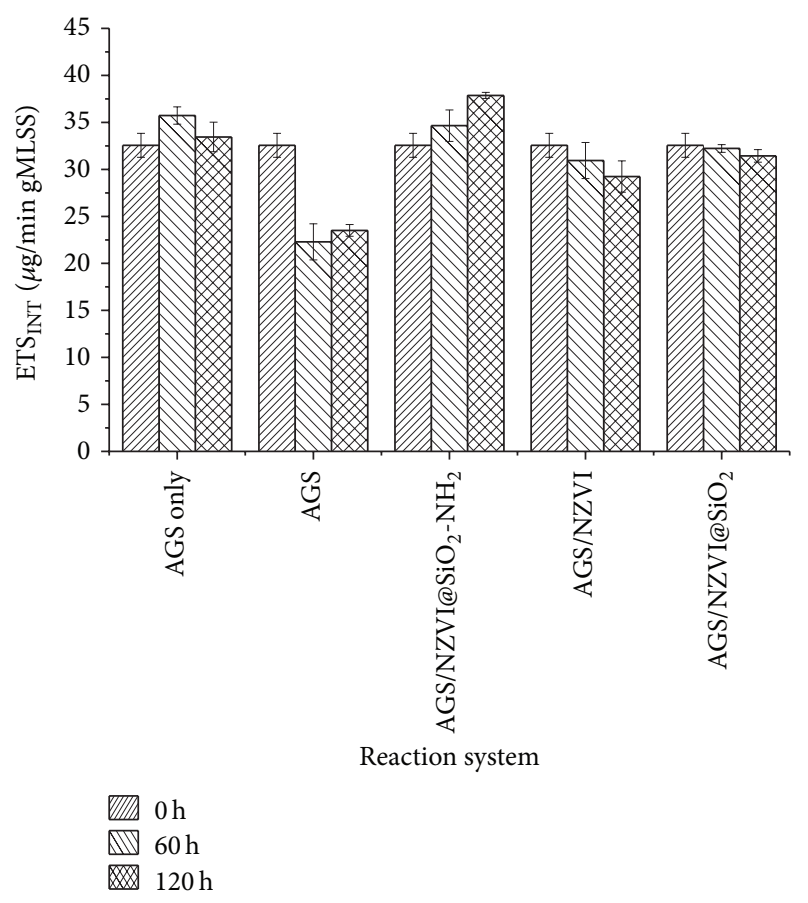

FIGURE 8: The changes of ETS $_{\text {INT }}$ of the anaerobic granule sludge under different concentrations of NZVI@SiO $2-\mathrm{NH}_{2}$ before and after being exposed to 2,4,6-TCP.

in Figure 8. The experimental results illustrated that longterm exposure on the 2,4,6-TCP could decrease the activity of anaerobic granule sludge. For example, the ETS activity of the exposed anaerobic granular sludge was $29.7 \%$ lower than that of the control granular sludge at all-time points. Meanwhile, the ETS activity of anaerobic granular sludge was stabled at $87.4 \%, 94.0 \%$, and $113.2 \%$ of the control granular sludge after $120 \mathrm{~h}$ of experiment process in the combination of AGS/NZVI, AGS/NZVI@SiO $\mathrm{NH}_{2}$ system, respectively. NZVI@SiO $2-\mathrm{NH}_{2}$ did not exert much stimulation and inactivation on the ETS activity of the anaerobic bacteria at the initial process of the experiment, because the core $\mathrm{nFe}^{0}$ was avoided directly contacting with microorganism by the surface-modified $\mathrm{SiO}_{2}$ shell. It can be observed that the addition of $\mathrm{NZVI@SiO} 2-\mathrm{NH}_{2}$ to anaerobic biodegradation system could enhance the activity of sludge and reduce the adverse influence of 2,4,6-TCP.

3.4. Effect of NZVI@SiO $\mathrm{N}_{2} \mathrm{NH}_{2}$ Dosage. Four identical batch microcosm experiments were operated at different dosages of $0.1,0.2,0.5$, and $1 \mathrm{~g} / \mathrm{L}$ in parallel for 120 hours to evaluate the removal rate of 2,4,6-TCP. The removal rate of 2,4,6-TCP as a function of time was presented in Figure 9. It can be observed that high removal rate of 2,4,6-TCP occurred when the NZVI@SiO ${ }_{2}-\mathrm{NH}_{2}$ dosage increased in the anaerobic granular sludge system. For example, the removal rate of $2,4,6$-TCP was found to be $80.7 \%, 87.4 \%, 95.4 \%$, and $96.6 \%$, respectively, when the addition dosage of NZVI@SiO $2-\mathrm{NH}_{2}$ to the anaerobic system was $0.1,0.2,0.5$, and $1 \mathrm{~g} / \mathrm{L}$. In addition, the concentration of 2,4,6-TCP in combined system was obviously deceased in the first $10-12 \mathrm{~h}$ of the experiment, which indicated that 2,4,6-TCP can be directly chemically reduced and/or be adsorbed on the surface layer of NZVI@SiO $-\mathrm{NH}_{2}$. The adsorptive and active sites on the surface of $\mathrm{NZVI@SiO}_{2}-$ $\mathrm{NH}_{2}$ increased when the amount of $\mathrm{NZVI@SiO}-\mathrm{NH}_{2}$ increased. Moreover, adding NZVI@SiO ${ }_{2}-\mathrm{NH}_{2}$ dosage to anaerobic granule sludge system is capable of providing more electron donors to promote anaerobic metabolic processes, and the corrosion process of $\mathrm{NZVI@SiO} 2-\mathrm{NH}_{2}$ can produce $\mathrm{Fe}^{2+} / \mathrm{Fe}^{3+}$ and hydrogen which can be used as minerals for the anaerobic microorganisms; thereby, the remnants of pollutants and toxic intermediate products could be further 


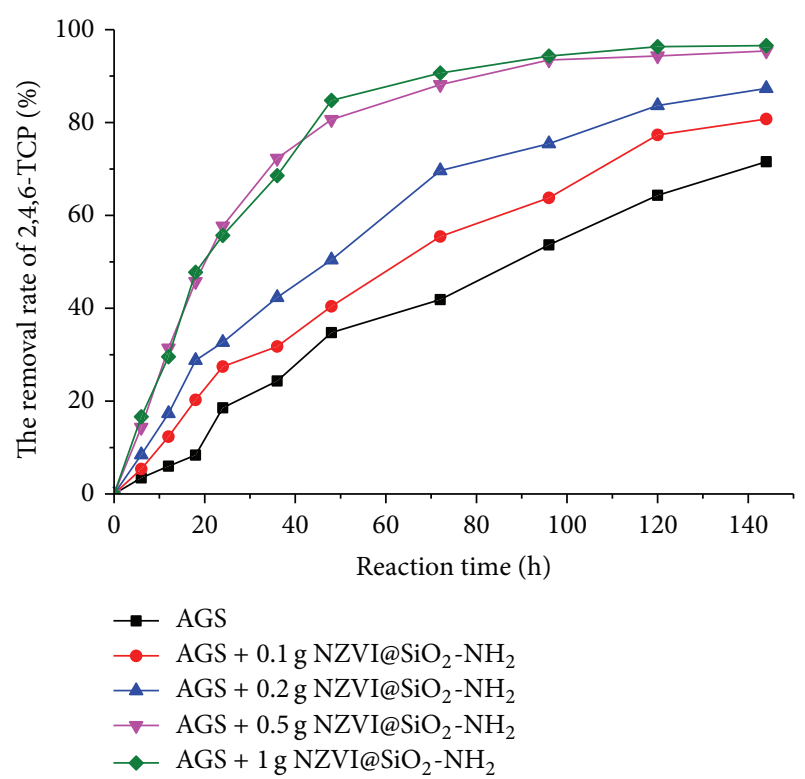

FIGURE 9: The degradation curves of 2,4,6-TCP by the anaerobic treatment process $\left(T=35 \pm 0.1^{\circ} \mathrm{C}, \mathrm{pH}=7.0\right.$, initial concentration of 2,4,6-TCP $\left(C_{0}\right)=50 \mathrm{mg} / \mathrm{L}$, anaerobic granular sludge $=10 \mathrm{~g} \mathrm{VSS}$, and stirring rate $=150 \mathrm{rpm}$ ).

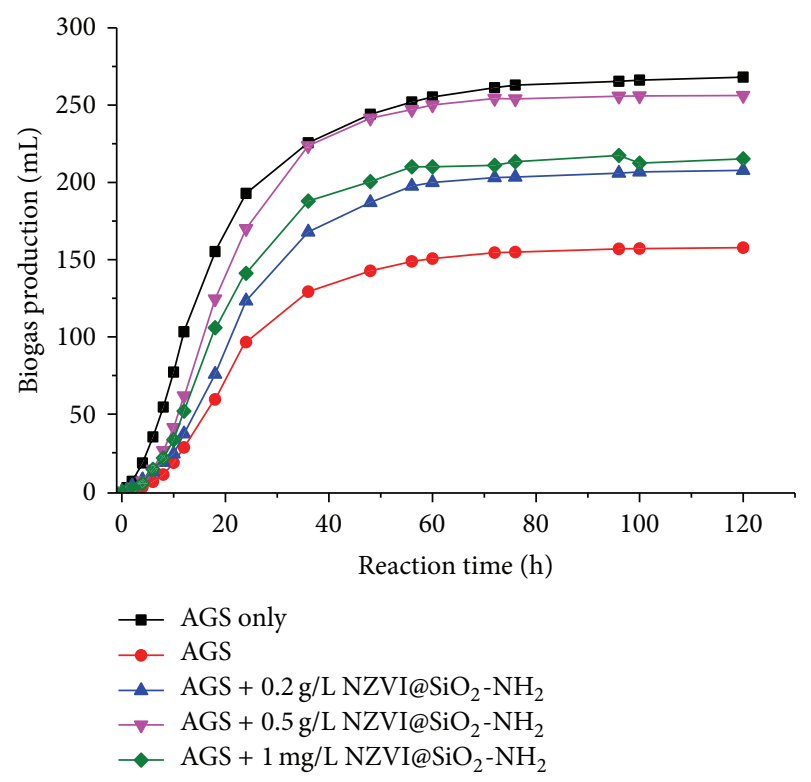

Figure 10: The production curves of $\mathrm{CH}_{4}$ in different anaerobic treatment process with and without $\mathrm{NZVI@SiO}-\mathrm{NH}_{2}$ at $\mathrm{pH}$ 7.0.

removed biologically by the attached microorganism in the combined system.

Methanogenic activity test was used to determine the influence of $\mathrm{NZVI@SiO} 2-\mathrm{NH}_{2}$ dosage on the anaerobic sludge activity in various anaerobic processes. Figure 10 showed the summary of the cumulative biogas productions with the function of $\mathrm{NZVI@SiO} 2-\mathrm{NH}_{2}$ in anaerobic methanogenic process. The accumulative production of biogas of the seed granular sludge at $35^{\circ} \mathrm{C}$ was $268.1 \mathrm{~mL}$ in the AGS only system. When the anaerobic system was exposed to $50 \mathrm{mg} / \mathrm{L}$ of 2,4,6-TCP, the cumulative production of biogas decreased to $157.7 \mathrm{~mL}$, far lower than the AGS only. The reason may be that chemical 2,4,6-TCP had a significant inhibitory effect on methanogenic activity of anaerobic microorganism, which affected the 2,4,6-TCP biological dechlorination and final mineralization by anaerobic microorganism. Maintaining a sufficient microbial activity was essential for a stable anaerobic treatment system on unfavorite condition. With increasing the dosage of $\mathrm{NZVI@SiO} 2_{-}^{-}$ $\mathrm{NH}_{2}$ from $0.1 \mathrm{~g} / \mathrm{L}, 0.2 \mathrm{~g} / \mathrm{L}$, and $0.51 \mathrm{~g} / \mathrm{L}$ to $1 \mathrm{~g} / \mathrm{L}$, obvious increase of the cumulative production of biogas in the integrated AGS/NZVI@SiO ${ }_{2}-\mathrm{NH}_{2}$ system during the operation was observed. And among these dosages of $\mathrm{NZVI@SiO} 2^{-}$ $\mathrm{NH}_{2}$, the cumulative production of biogas $(0.2 \mathrm{~g} / \mathrm{L}$ and $0.5 \mathrm{~g} / \mathrm{L}$ ) increased by $31.7 \%$ and $62.4 \%$, respectively, more than that of the AGS system at $120 \mathrm{~h}$. That is to say, the methanogenic activity of the seed sludge increased with the increasing dosage of $\mathrm{NZVI@SiO} \mathrm{SH}_{2}$. The results implied that the activity of anaerobic microorganisms was significantly influenced by the function of the added iron nanoparticles. However, the results of cumulative biogas productions in anaerobic dechlorination processes with the different dosage of NZVI@SiO $-\mathrm{NH}_{2}$ were largely different from the removal rate of 2,4,6-TCP (Figure 9). The methanogenic activity of $1 \mathrm{~g} / \mathrm{L}$ of $\mathrm{NZVI@SiO}-\mathrm{NH}_{2}$ was considerably lower than that of $0.5 \mathrm{~g} / \mathrm{L}$, which means that the anaerobic system should be operated with appropriate concentration of iron nanoparticles.

3.5. Effect of the Initial Concentration of $\mathrm{Fe}^{2+}$. The effect of $\mathrm{Fe}^{2+}$ on the removal of 2,4,6-TCP in combined anaerobic granule sludge/NZVI@SiO $2-\mathrm{NH}_{2}$ system was investigated at initial neutral $\mathrm{pH}$, as shown in Figure 11. When only $100 \mathrm{mg} / \mathrm{L}$ of $\mathrm{Fe}^{2+}$ was presented in the reaction solution, the concentration of 2,4,6-TCP kept near $48 \pm 0.1 \mathrm{mg} / \mathrm{L}$ within $120 \mathrm{~h}$. However, the existence of $\mathrm{Fe}^{2+}$ may involve the reactions $\left(\mathrm{Fe}^{2+} \rightarrow \mathrm{Fe}^{3+}+\mathrm{e}^{-}\right)$which might be attributed to increasing $\mathrm{Fe}^{2+}$ reducing ability. The result obviously indicated that the ferrous ion was not the major source on the removal of 2,4,6-TCP. When $50 \mathrm{mg} / \mathrm{L}$ to $200 \mathrm{mg} / \mathrm{L} \mathrm{Fe}^{2+}$ was added to the AGS/NZVI@SiO $-\mathrm{NH}_{2}$ system, the removal rate of $2,4,6$-TCP decreased from $87.8 \%$ to $75.2 \%$, indicating that the ferrous ion in the mixed system of $\mathrm{NZVI@SiO} 2-\mathrm{NH}_{2}$ and anaerobic sludge did not enhance the 2,4,6-TCP degradation. The higher content of $\mathrm{Fe}^{2+}$ had a negative effect on the 2,4,6TCP degradation in the integrated AGS/NZVI@SiO $-\mathrm{NH}_{2}$ system. Besides, Table 1 has shown that the added $\mathrm{Fe}^{2+}$ had a significant inhibitory effect on methanogenic activity of AGS/NZVI@SiO ${ }_{2}-\mathrm{NH}_{2}$ system. The specific methanogenic activity decreased from $48.7 \mathrm{~mL} / \mathrm{g}$ VSS d to $37.5 \mathrm{~mL} / \mathrm{g}$ VSS d at $200 \mathrm{mg} / \mathrm{L}$ of $\mathrm{Fe}^{2+}$. This may be because higher concentration of $\mathrm{Fe}^{2+}(200 \mathrm{mg} / \mathrm{L})$ decreased very quickly in the reaction system with a large amount of amorphous colloidal $\mathrm{Fe}(\mathrm{OH})_{3}$. These iron precipitates can be attached to the surface of iron nanoparticles and anaerobic granular sludge, which would decrease the reduction ability of iron 
TABLE 1: The effect of $\mathrm{Fe}^{2+}$ on methanogenic activity of $\mathrm{NZVI@SiO}_{2}-$ $\mathrm{NH}_{2}$ /anaerobic granule sludge system.

\begin{tabular}{lccc}
\hline $\begin{array}{l}\mathrm{Fe}^{2+} \text { dosage } \\
(\mathrm{mg} / \mathrm{L})\end{array}$ & $\begin{array}{c}\text { Maximum gas } \\
\text { output } \\
(\mathrm{mL} / \mathrm{h})\end{array}$ & $\begin{array}{c}\text { Specific } \\
\text { methanogenic activity } \\
(\mathrm{mL} / \mathrm{g} \mathrm{VSS} \mathrm{d})\end{array}$ & $\begin{array}{c}\text { Relative } \\
\text { activity }\end{array}$ \\
\hline 0 & $15.8 \pm 0.62$ & $48.72 \pm 2.20$ & - \\
50 & $13.3 \pm 0.75$ & $45.67 \pm 0.67$ & $93.74 \%$ \\
100 & $10.5 \pm 1.05$ & $42.59 \pm 2.25$ & $87.42 \%$ \\
200 & $9.7 \pm 0.43$ & $37.56 \pm 0.93$ & $77.09 \%$ \\
\hline
\end{tabular}

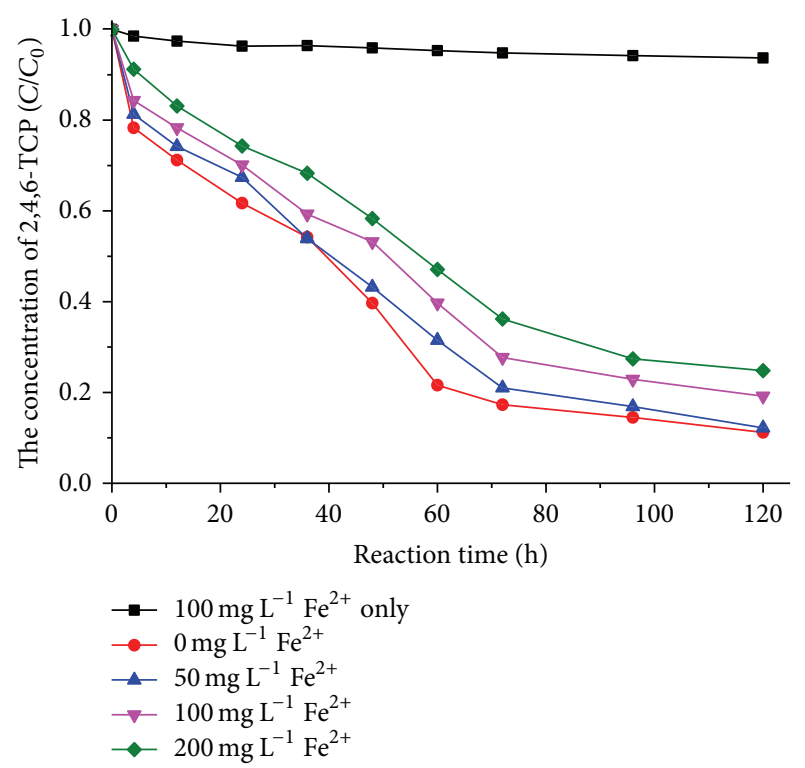

FIgURE 11: The effect of $\mathrm{Fe}^{2+}$ on the removal of 2,4,6-TCP in $\mathrm{NZVI@SiO}-\mathrm{NH}_{2}$-anaerobic granule sludge system.

nanoparticles and the activity of anaerobic microorganisms. Thus, this would further affect the degradation efficiency and methanogenic activity of anaerobic microorganisms. Besides, the concentration of $\mathrm{Fe}^{2+}$ gradually raised and remained at a certain concentration in this combined system (Figure 6(a)), suggesting that the added $\mathrm{NZVI@SiO} 2-\mathrm{NH}_{2}$ could continue to release $\mathrm{Fe}^{2+}$ as the supply of electronics and elements for $\mathrm{NZVI@SiO} 2-\mathrm{NH}_{2}$-anaerobic granule sludge system.

\section{Conclusion}

NZVI@SiO $-\mathrm{NH}_{2}$ was successfully synthesized by the surface functionalization of NZVI using TEOS and APTMS. The obtained NZVI@SiO $2-\mathrm{NH}_{2}$ had a good dispersibility and antioxidant capacity and can be stored in the air for long time. Compared to the NZVI, NZVI@SiO $-\mathrm{NH}_{2}$ showed an appreciable reactivity with 2,4,6-TCP. The determined $K_{\mathrm{obs}}$ was $0.043 \mathrm{~h}^{-1}$ at the neutral condition, much higher than that of NZVI. The combined anaerobic granule sludge system/NZVI@SiO $2-\mathrm{NH}_{2}$ had significant synergistic effects on the removal of 2,4,6-TCP. More than $94.6 \%$ of $2,4,6-$ TCP was removed from the combined AGS/NZVI@SiO ${ }_{2}^{-}$ $\mathrm{NH}_{2}$ system during the operation processes. The added
NZVI@SiO $-\mathrm{NH}_{2}$ to microbial system can decrease the toxic inhibition of 2,4,6-TCP, resulting in improved cumulative amount of methane production and ETS activity. Moreover, the combination of AGS/NZVI@SiO $2-\mathrm{NH}_{2}$ system should be operated with appropriate concentration of NZVI@SiO $-\mathrm{NH}_{2}$. The 2,4,6-TCP degradation and methane production with extra $\mathrm{Fe}^{2+}(>50 \mathrm{mg} / \mathrm{L})$ in the combined AGS/NZVI@SiO $-\mathrm{NH}_{2}$ were remarkably adverse on the performance and methanogenic activity of AGS-NZVI@SiO $2^{-}$ $\mathrm{NH}_{2}$. The novel of modified nanoparticle could be an effective and promising material in the anaerobic treatment system for removal of CPs from industrial wastewater. However, further study should be carried out to control the efficiency and activity of microbial system in application of the novel $\mathrm{NZVI@SiO} 2-\mathrm{NH}_{2}$ in situ remediation of industrial wastewater.

\section{Conflict of Interests}

The authors declare that there is no conflict of interests regarding the publication of this paper.

\section{Acknowledgments}

This research has been supported by National Natural Science Foundation of China (no. 51208206), Guangdong Provincial Department of Science (no. 2012A032300015), Guangdong Natural Science Foundation (no. S2011040000389), China Postdoctoral Science Foundation, State Key Laboratory of Pulp and Paper Engineering in China (201213), and the Fundamental Research Funds for the Central Universities (2013ZZ0031).

\section{References}

[1] B. H. Hameed, I. A. W. Tan, and A. L. Ahmad, "Adsorption isotherm, kinetic modeling and mechanism of 2,4,6trichlorophenol on coconut husk-based activated carbon," Chemical Engineering Journal, vol. 144, no. 2, pp. 235-244, 2008.

[2] X. Zhang, H. Li, Q. Qiu, Y. Qi, D. Huang, and Y. Zhang, "2,4-Dichlorophenol induces global DNA hypermethylation through the increase of S-adenosylmethionine and the upregulation of DNMTs mRNA in the liver of goldfish Carassius auratus," Comparative Biochemistry and Physiology C, Toxicology and Pharmacology, vol. 160, no. 1, pp. 54-59, 2014.

[3] R. Cheng, J.-L. Wang, and W.-X. Zhang, "Comparison of reductive dechlorination of p-chlorophenol using $\mathrm{Fe} 0$ and nanosized Fe0," Journal of Hazardous Materials, vol. 144, no. 1-2, pp. 334-339, 2007.

[4] J.-H. Choi, Y.-H. Kim, and S. J. Choi, "Reductive dechlorination and biodegradation of 2,4,6-trichlorophenol using sequential permeable reactive barriers: laboratory studies," Chemosphere, vol. 67, no. 8, pp. 1551-1557, 2007.

[5] L. Ren, J. Zhang, Y. Li, and C. Zhang, "Preparation and evaluation of cattail fiber-based activated carbon for 2,4dichlorophenol and 2,4,6-trichlorophenol removal," Chemical Engineering Journal, vol. 168, no. 2, pp. 553-561, 2011.

[6] H.-C. Liang and X.-Z. Li, "Effects of structure of anodic $\mathrm{TiO}_{2}$ nanotube arrays on photocatalytic activity for the degradation 
of 2,3-dichlorophenol in aqueous solution," Journal of Hazardous Materials, vol. 162, no. 2-3, pp. 1415-1422, 2009.

[7] P. Cañizares, J. Lobato, R. Paz, M. A. Rodrigo, and C. Sáez, "Electrochemical oxidation of phenolic wastes with borondoped diamond anodes," Water Research, vol. 39, no. 12, pp. 2687-2703, 2005.

[8] Z. Li, Y. Inoue, D. Suzuki, L. Ye, and A. Katayama, "Longterm anaerobic mineralization of pentachlorophenol in a continuous-flow system using only lactate as an external nutrient," Environmental Science and Technology, vol. 47, no. 3, pp. 1534-1541, 2013.

[9] L. Beristain-Montiel, J. Gómez, O. Monroy, F. M. Cuervo-López, and F. Ramírez-Vives, "Biodegradation of 2-chlorophenol (2CP) in an anaerobic sequencing batch reactor (ASBR)," Water Science and Technology, vol. 65, no. 10, pp. 1721-1728, 2012.

[10] X. W. Liu, R. He, and D. S. Shen, "Studies on the toxic effects of pentachlorophenol on the biological activity of anaerobic granular sludge," Journal of Environmental Management, vol. 88, no. 4, pp. 939-946, 2008.

[11] D. Puyol, J. L. Sanz, J. J. Rodriguez, and A. F. Mohedano, "Inhibition of methanogenesis by chlorophenols: a kinetic approach," New Biotechnology, vol. 30, no. 1, pp. 51-61, 2012.

[12] R. A. Crane and T. B. Scott, "Nanoscale zero-valent iron: future prospects for an emerging water treatment technology," Journal of Hazardous Materials, vol. 211-212, pp. 112-125, 2012.

[13] Y. T. Wei, S. C. Wu, S. W. Yang, C. H. Che, H. L. Lien, and D. H. Huang, "Biodegradable surfactant stabilized nanoscale zero-valent iron for in situ treatment of vinyl chloride and 1,2dichloroethane," Journal of Hazardous Materials, vol. 211-212, pp. 373-380, 2012.

[14] L. Alidokht, A. R. Khataee, A. Reyhanitabar, and S. Oustan, "Reductive removal of $\mathrm{Cr}(\mathrm{VI})$ by starch-stabilized $\mathrm{Fe}^{0}$ nanoparticles in aqueous solution," Desalination, vol. 270, no. 1-3, pp. 105-110, 2011.

[15] T. Satapanajaru, C. Chompuchan, P. Suntornchot, and P. Pengthamkeerati, "Enhancing decolorization of Reactive Black 5 and Reactive Red 198 during nano zerovalent iron treatment," Desalination, vol. 266, no. 1-3, pp. 218-230, 2011.

[16] C. Ren, Y. Li, J. Li, G. Sheng, L. Hu, and X. Zheng, "Immobilization of nanoscale zero valent iron on organobentonite for accelerated reduction of nitrobenzene," Journal of Chemical Technology \& Biotechnology, vol. 89, pp. 1961-1966, 2014.

[17] Y. W. Liu, Y. B. Zhang, X. Quan, J. X. Zhang, H. M. Zhao, and S. O. Chen, "Effects of an electric field and zero valent iron on anaerobic treatment of azo dye wastewater and microbial community structures," Bioresource Technology, vol. 102, no. 3, pp. 2578-2584, 2011.

[18] S. Jagadevan, M. Jayamurthy, P. Dobson, and I. P. Thompson, "A novel hybrid nano zerovalent iron initiated oxidationbiological degradation approach for remediation of recalcitrant waste metalworking fluids," Water Research, vol. 46, no. 7, pp. 2395-2404, 2012.

[19] A. C. de Velosa and R. F. P. Nogueira, "2,4-Dichlorophenoxyacetic acid $(2,4-\mathrm{D})$ degradation promoted by nanoparticulate zerovalent iron (nZVI) in aerobic suspensions," Journal of Environmental Management, vol. 121, pp. 72-79, 2013.

[20] S. Karri, R. Sierra-Alvarez, and J. A. Field, "Zero valent iron as an electron-donor for methanogenesis and sulfate reduction in anaerobic sludge," Biotechnology and Bioengineering, vol. 92, no. 7, pp. 810-819, 2005.

[21] Y. Liu, T. Phenrat, and G. V. Lowry, "Effect of TCE concentration and dissolved groundwater solutes on NZVI-promoted TCE dechlorination and $\mathrm{H}_{2}$ evolution," Environmental Science and Technology, vol. 41, no. 22, pp. 7881-7887, 2007.

[22] L. Zhu, H.-Z. Lin, J.-Q. Qi, X.-Y. Xu, and H.-Y. Qi, "Effect of $\mathrm{H}_{2}$ on reductive transformation of $\mathrm{p}$-CINB in a combined ZVIanaerobic sludge system," Water Research, vol. 46, no. 19, pp. 6291-6299, 2012.

[23] L. Zhu, H. Lin, J. Qi, and X. Xu, "Enhanced transformation and dechlorination of p-chloronitrobenzene in the combined ZVIanaerobic sludge system," Environmental Science and Pollution Research, vol. 20, no. 9, pp. 6119-6127, 2013.

[24] K. F. Chen, T. Y. Yeh, C. M. Kao, W. P. Sung, and C. C. Lin, "Application of nanoscale zero-valent iron (nZVI) to enhance microbial reductive dechlorination of TCE: a feasibility study," Current Nanoscience, vol. 8, no. 1, pp. 55-59, 2012.

[25] Y. M. Li, Y. Zhang, J. F. Li, G. D. Sheng, and X. M. Zheng, "Enhanced reduction of chlorophenols by nanoscale zerovalent iron supported on organobentonite," Chemosphere, vol. 92, no. 4, pp. 368-374, 2013.

[26] B.-W. Zhu, T.-T. Lim, and J. Feng, "Reductive dechlorination of 1,2,4-trichlorobenzene with palladized nanoscale $\mathrm{Fe}^{0}$ particles supported on chitosan and silica," Chemosphere, vol. 65, no. 7, pp. 1137-1145, 2006.

[27] Z.-M. Xiu, Z.-H. Jin, T.-L. Li, S. Mahendra, G. V. Lowry, and P. J. J. Alvarez, "Effects of nano-scale zero-valent iron particles on a mixed culture dechlorinating trichloroethylene," Bioresource Technology, vol. 101, no. 4, pp. 1141-1146, 2010.

[28] S. Laumann, V. Micić, and T. Hofmann, "Mobility enhancement of nanoscale zero-valent iron in carbonate porous media through co-injection of polyelectrolytes," Water Research, vol. 50, pp. 70-79, 2014.

[29] B. Zou, Y. Hu, F. Cui, L. Jiang, D. Yu, and H. Huang, "Effect of surface modification of low cost mesoporous $\mathrm{SiO}_{2}$ carriers on the properties of immobilized lipase," Journal of Colloid and Interface Science, vol. 417, pp. 210-216, 2014.

[30] J. Wang, S. Zheng, Y. Shao, J. Liu, Z. Xu, and D. Zhu, "Aminofunctionalized $\mathrm{Fe}_{3} \mathrm{O}_{4} @ \mathrm{SiO}_{2}$ core-shell magnetic nanomaterial as a novel adsorbent for aqueous heavy metals removal," Journal of Colloid and Interface Science, vol. 349, no. 1, pp. 293-299, 2010.

[31] Z. Lu, G. Wang, J. Zhuang, and W. Yang, "Effects of the concentration of tetramethylammonium hydroxide peptizer on the synthesis of $\mathrm{Fe}_{3} \mathrm{O}_{4} / \mathrm{SiO}_{2}$ core/shell nanoparticles," Colloids and Surfaces A: Physicochemical and Engineering Aspects, vol. 278, no. 1-3, pp. 140-143, 2006.

[32] Y. Kuang, Y. Zhou, Z. Chen, M. Megharaj, and R. Naidu, "Impact of $\mathrm{Fe}$ and $\mathrm{Ni} / \mathrm{Fe}$ nanoparticles on biodegradation of phenol by the strain Bacillus fusiformis (BFN) at various $\mathrm{pH}$ values," Bioresource Technology, vol. 136, pp. 588-594, 2013.

[33] B. P. McNicholl, J. W. McGrath, and J. P. Quinn, "Development and application of a resazurin-based biomass activity test for activated sludge plant management," Water Research, vol. 41, no. 1, pp. 127-133, 2007.

[34] L. Isac and C. Arnáiz, "Biomass characterization and biological activity tests in wastewater treatment. Applicability to the assessment of inhibitory and toxic pollutants," Afinidad, vol. 62, no. 517, pp. 197-210, 2005.

[35] J. T. Nurmi, P. G. Tratnyek, V. Sarathy et al., "Characterization and properties of metallic iron nanoparticles: spectroscopy, electrochemistry, and kinetics," Environmental Science and Technology, vol. 39, no. 5, pp. 1221-1230, 2005.

[36] X. Lv, Y. Hu, J. Tang, T. Sheng, G. Jiang, and X. Xu, "Effects of co-existing ions and natural organic matter on removal of 
chromium (VI) from aqueous solution by nanoscale zero valent iron (nZVI)- $\mathrm{Fe}_{3} \mathrm{O}_{4}$ nanocomposites," Chemical Engineering Journal, vol. 218, pp. 55-64, 2013.

[37] J. Wan, J. Wan, Y. Ma, M. Huang, Y. Wang, and R. Ren, "Reactivity characteristics of $\mathrm{SiO}_{2}$-coated zero-valent iron nanoparticles for 2,4-dichlorophenol degradation," Chemical Engineering Journal, vol. 221, pp. 300-307, 2013.

[38] X.-W. Liu, R. He, and D.-S. Shen, "Studies on the toxic effects of pentachlorophenol on the biological activity of anaerobic granular sludge," Journal of Environmental Management, vol. 88, no. 4, pp. 939-946, 2008.

[39] M.-H. Huang, Y.-M. Li, and G.-W. Gu, "Toxicity reduction of municipal wastewater by anaerobic-anoxic-oxic process," Biomedical and Environmental Sciences, vol. 23, no. 6, pp. 481486, 2010.

[40] L. Huang, Y. Shi, N. Wang, and Y. Dong, "Anaerobic/aerobic conditions and biostimulation for enhanced chlorophenols degradation in biocathode microbial fuel cells," Biodegradation, vol. 25, pp. 615-632, 2014.

[41] Y. H. Huang and T. C. Zhang, "Effects of dissolved oxygen on formation of corrosion products and concomitant oxygen and nitrate reduction in zero-valent iron systems with or without aqueous $\mathrm{Fe}^{2+}$," Water Research, vol. 39, no. 9, pp. 1751-1760, 2005.

[42] L. Huang, G. Sun, T. Yang, B. Zhang, Y. He, and X. Wang, "A preliminary study of anaerobic treatment coupled with microelectrolysis for anthraquinone dye wastewater," Desalination, vol. 309, pp. 91-96, 2013. 

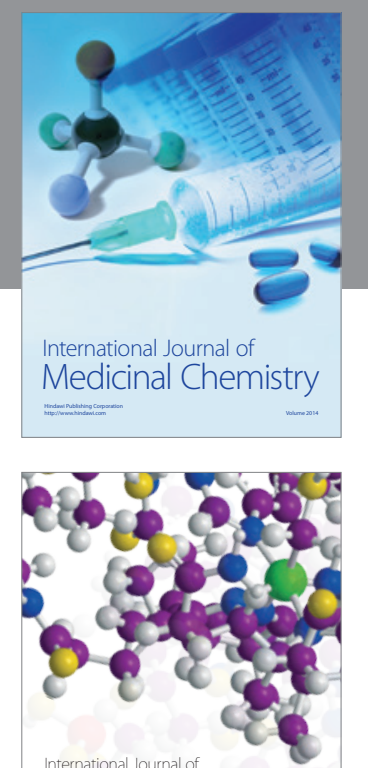

\section{Carbohydrate} Chemistry

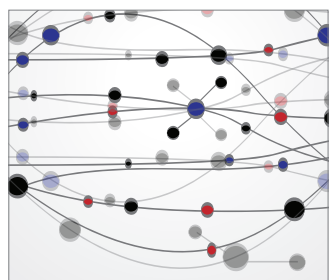

The Scientific World Journal
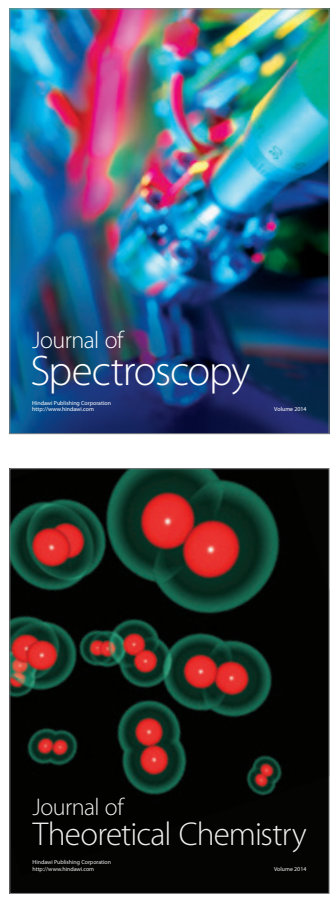
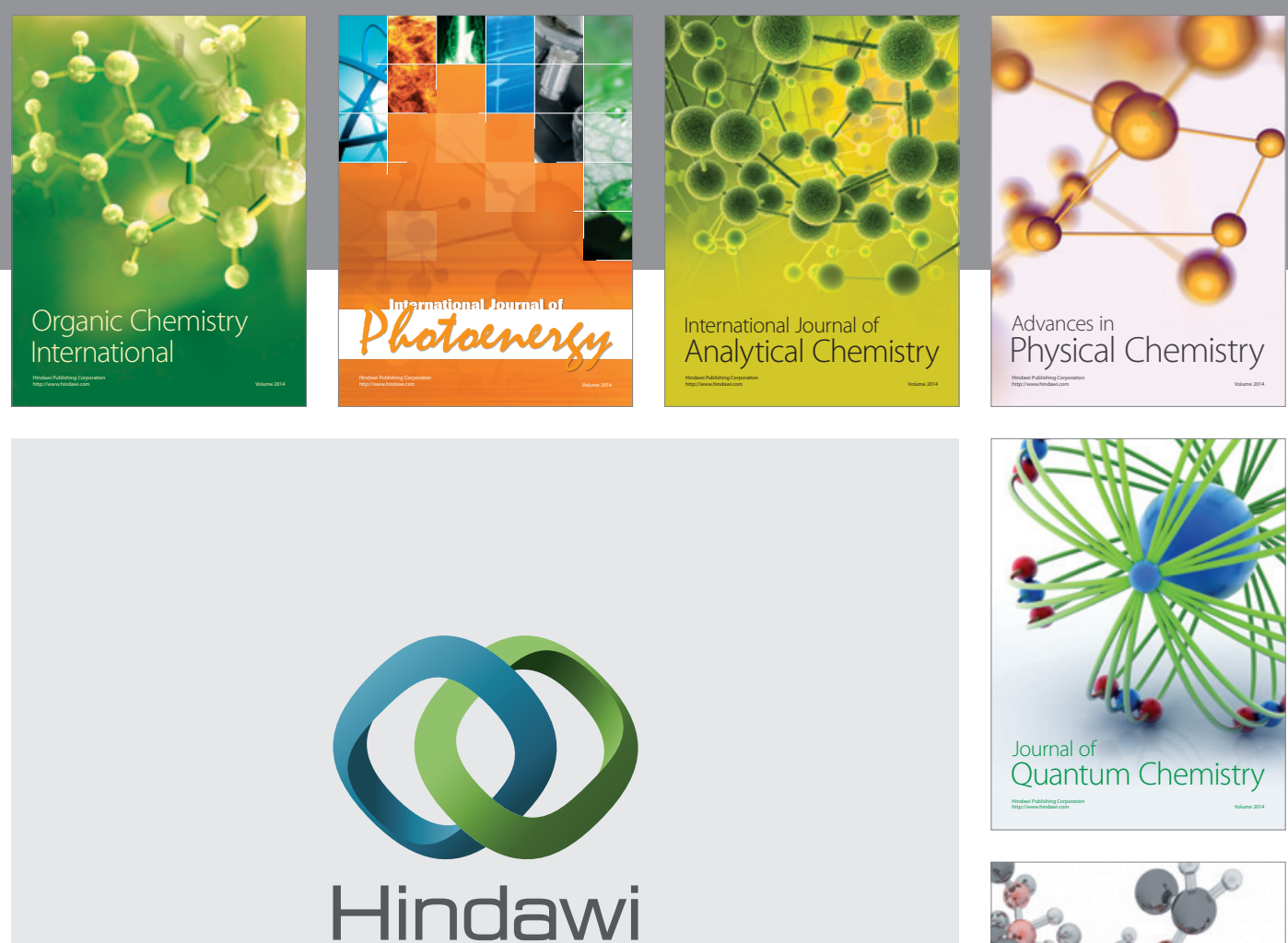

Submit your manuscripts at

http://www.hindawi.com

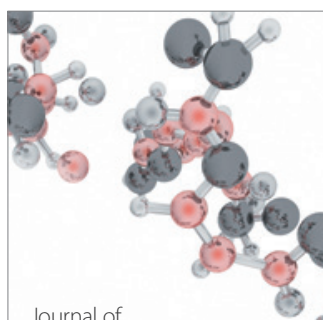

Analytical Methods

in Chemistry

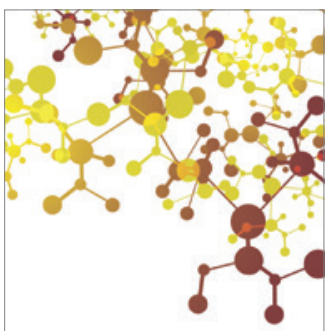

Journal of

Applied Chemistry

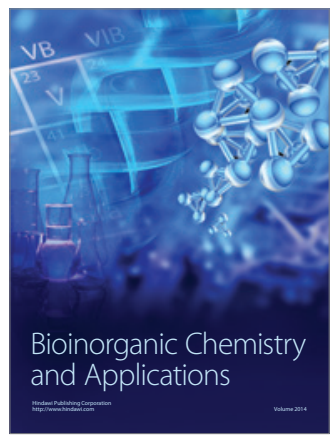

Inorganic Chemistry
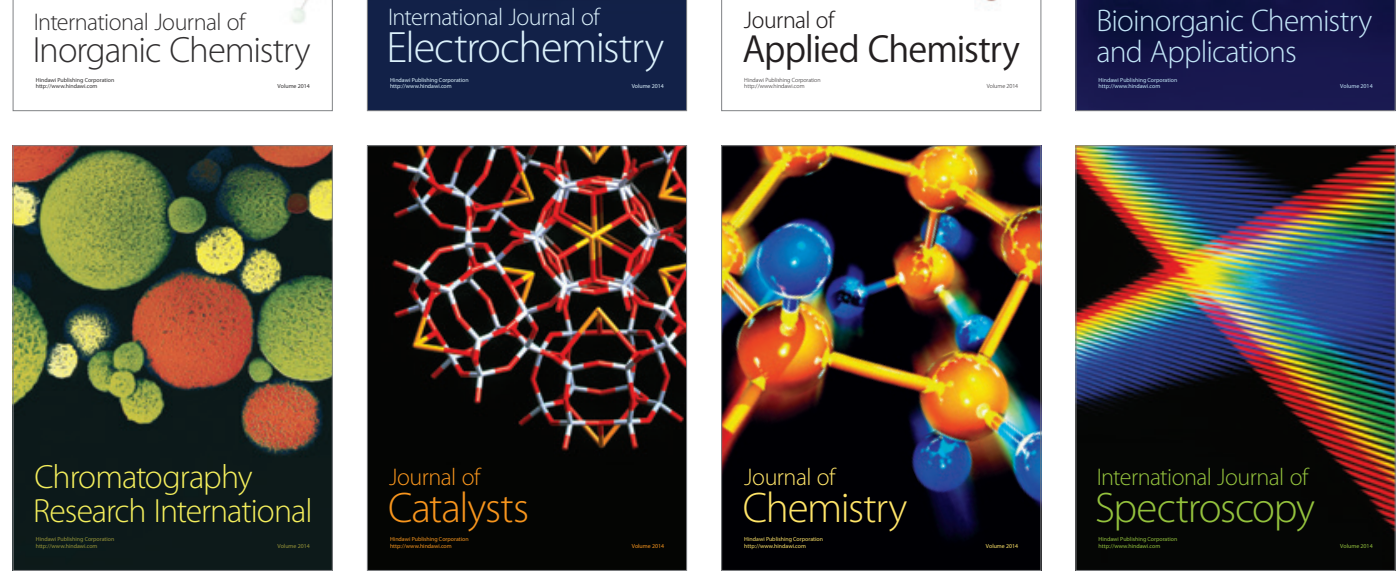